DOI 10.15393/j9.art.2018.5401

УДК 821.161.1.09“18”

Елена Алексеевна Федорова

(Ярославль, Рьбинск, Российская Федерация)

sole11@yandex.ru

Ирина Федоровна Ковалева

(Рыбинск, Российская Федерация)

kirinaf@yandex.ru

\title{
Жанровое содержание народных легенд в литературной обработке Е. Н. Опочинина
}

Аннотация. В статье дан анализ жанровых и сюжетных особенностей литературных обработок народных легенд, записанных Е. Н. Опочининым в Рыбинском уезде Ярославской губернии (1909-1916). Новизна исследования обусловлена тем, что эти легенды еще не введены в научный оборот. Их сопоставление с записями легенд А. Н. Афанасьева позволяет расширить представление о духовно-нравственных ценностях русского народа. Легенда как жанр является средством сохранения сюжетных элементов мифологии, аксиологические функции ее мотивов проявляются в сюжете. Легенды можно разделить на те, которые связаны с нарушением божественного порядка, и те, которые связаны с его восстановлением. В легендах раскрываются особенности христианского мироощущения: потребность в молитве, почитание святых и их образов, соблюдение иерархии в семье и обществе, труд, честность, трезвость, милосердие и взаимопомощь, ответственность за слова и дела, вера в Промысел Божий. «Память жанра» легенды обнаруживается в литературных произведениях. Следствием нарушения божественного порядка в легендах и литературных произведениях становится утрата смирения и чувства меры, маловерие, посягательство на чужое имущество. Восстановление нарушенного порядка происходит благодаря заступничеству святых и добродетельных детей за грешников.

Ключевые слова: Е. Н. Опочинин, народная легенда, сюжет, мотив, жанр, аксиология, духовно-нравственные ценности, «память жанра»

$\mathrm{O}$

дним из важнейших свойств художественной литературы, обогащающих ее, является фольклоризм, поскольку фольклор как «форма национального самосознания» вносит в литературу «подлинные черты народности» [Азадовский: 46]. В. Я. Пропп особенно выделял легенду, утверждая, что это

() Е. А. Федорова, И. Ф. Ковалева, 2018 
«наиболее национальный из всех жанров русского фольклора» [Пропп: 273].

А. Н. Афанасьев, русский собиратель фольклора, известный своим интерсом к духовной культуре славянских народов, отмечал, что «народная песня и сказка $<. . .>$ не раз обращались к священному писанию и житиям святых и отсюда почерпали материал для своих повествований», а «в легендах заимствованный материал передается далеко не в совершенной чистоте; напротив, он более или менее подчиняется произволу народной фантазии, видоизменяется сообразно ее требованиям и даже связывается с теми преданиями и повериями, которые уцелели от эпохи доисторической и которые, повидимому, так противуположны началам христианского учения» [Афанасьев, 1859: 5-6]. После издания Афанасьевым (1859 г.) сборника русских народных легенд историк, этнограф, литературовед А. Н. Пыпин в стремлении определить жанровую специфику христианской легенды отметил, что она «останавливается исключительно на предметах, принадлежащих к области христианских верований и религиозной морали» [Пыпин: 181].

В «Литературной энциклопедии терминов и понятий» легенда (от латинского legenda - «то, что должно быть прочитано») определяется как жанр фольклорной несказочной прозы, осмысляющий чудесные события как достоверные [Зуева: 432-433]. В отличие от сказки, в которой очевидна установка на вымысел, легенда претендует на историзм, конкретику, реалистичность, одновременно обращаясь к области религиозно-мистического опыта. Г. А. Левинтон утверждал, что «легенда занимает место среди жанров, лежащих между мифом и историческим описанием». Ее особенность - «приуроченность к историческому времени» или «К переходу от мифологического времени к историческому» [Левинтон: 45].

По мнению А. А. Ухтомского, легенда соединяет прошлое и настоящее (создается в устной народной традиции, а затем уже записывается) и закрепляет те духовные доминанты, которые будут переданы последующим поколениям. Легенда включает в себя историческое повествование и его поэтическую обработку [Ухтомский: 29-33]. 
Р. Г. Назиров объяснял сходные фольклорные мотивы у разных народов особенностями мифологической картины мира. Так, в основе запрета оглядываться назад и наказания за его нарушение в мифах разных народов и Ветхом Завете (жена Лота превращается в соляной столп (Быт. 19)), по его мнению, «лежит архаическая черта человеческой психологии: неразличение субъекта и объекта. <...> Не видеть смертельной угрозы - это значит не быть увиденным ею» [Назиров: 35 ].

Одним из первых к изучению жанра легенды обратился А. Н. Веселовский. Он полагал, что легенда является средством перенесения сюжетных элементов мифологии в религиозную (христианскую) картину мира и показал как в фольклоре Западной Европы и России происходит развитие общих мотивов [Веселовский. Опыты... 1875-1877].

За основу классификация сказок и легенд в фольклоре берутся разные критерии: они систематизируются по жанрам, темам, сюжетам и мотивам. Первое издание народных сказок А. Н. Афанасьева (1855-1863) вышло без систематизации. При подготовке второго издания фольклорист классифицировал их, разделив на сказки о животных и о людях, последние, в свою очередь, - на волшебные и бытовые.

В настоящее время исследователи классифицируют сказки и легенды по системе Аарне-Томпсона (АТ). В 1910 г. финский фольклорист Антти Аарне предложил указатель сказочных типов, опираясь на их жанровую классификацию. Так, он выделил сказки о животных, собственно сказки (куда входят и легендарные сказки) и анекдоты. В 1912 г. им был составлен указатель финских этиологических легенд. Советский исследователь фольклора Н. П. Андреев в 1929 г. составил «Указатель сказочных сюжетов по системе Аарне». Опираясь на труды Аарне, американский фольклорист Стив Томпсон в 1965 г. составил указатель не только сюжетов сказок, но и их мотивов, принципы выделения которых у Томпсона были недостаточно определены (см.: [Азбелев]). В 1979 г. составлен сравнительный указатель сюжетов восточнославянских сказок (переизд. 2004 г.), над которым работали Л. Г. Бараг, И. П. Березовский, К. П. Кабашников, Н. В. Новиков [Сравнительный указатель сюжетов]. 
В. Я. Пропп систематизировал легенды по тематическому принципу, разделив их на легенды о святых и о грешниках, о семейных отношениях, космогонические и легенды о загробной жизни [Пропп: 125]. По классификации Т. В. Зуевой различаются этиологические (космогонические - о сотворении мира, этнологические - о начале человеческого рода, эсхатологические - о конце света), религиозно-назидательные (о Боге-Отце, о Христе, об ангелах и святых, о юродивых) и социально-утопические легенды [Зуева]. К. В. Чистов, в свою очередь, среди социально-утопических легенд, отражающих представления народа о справедливом социальном устройстве, выделял легенды «о золотом веке», «о далеких землях», «о возвращающемся избавителе» [Чистов]. Эти классификации необходимо дополнить также демонологическими легендами.

Среди литературных обработок народных легенд, записанных Е. Н. Опочининым в Рыбинском уезде Ярославской губернии в 1909-1916 гг. ${ }^{1}$, имеются этиологические (космогонические) легенды, где рассказывается о сотворении мира: «Как Бог век назначал человеку и домашней твари», «Откуда взялись водяные», «Гроза и окаянный» (ед. хр. 3, л. 1-8). В легенде «Как Бог век назначал человеку и домашней твари» Господь является на землю, чтоб навести порядок: установить, сколько лет будет жить человек и его домашние животные. Сначала он призывает животных, которые служат человеку, и предлагает лошади 30 лет жизни, а собаке и кошке - 20 лет. После вопроса Господа, довольны ли домашние животные этими сроками, каждый из них выказывает недовольство: последние 10 лет они не смогут как следует служить человеку, поэтому для них жизнь станет мучением. Животные просят Господа, чтобы он сократил им срок жизни на 10 лет. Господь соглашается и призывает человека, ему он дарит 40 лет жизни и также спрашивает, доволен ли человек. В ответ слышит просьбу прибавить ему срок жизни, поскольку после 40 лет жизнь человека только и начнется, дети подрастут, и человек просит Господа, чтобы Тот дал ему возможность увидеть, как будут жить дети и внуки. Господь соглашается и дарит человеку первые 10 лет от лошадиного срока жизни (в 50 лет «будешь ты везти тяготу не пуще коня»), вторые 10 лет - от собачьего срока жизни (в 60 лет 
«живи да оглядывайся»), третьи 10 лет - от кошачьего срока (в 70 лет «валяйся на печи да отдыхай!») (ед. хр. 3, л. 5-8). В этой легенде иносказательно раскрывается философская идея о разных этапах жизни человека. Остроумное сопоставление человеческой жизни с жизнью животных указывает на постепенное умалении возможностей человека после 40 лет. Подобной легенды нет в сборнике Афанасьева, но сюжет «срок жизни людей и животных» (АТ 828) является сквозным для народных легенд [Сравнительный указатель сюжетов].

В легендах «Гроза и окаянный», «Откуда взялись водяные» повествуется о том, как Гроза, по приказанию Господа, преследует нечистого духа и загоняет его сначала в осину, а потом - в воду. В легенде «Откуда взялись водяные» отражаются особенности отношения местных жителей к дарам природы: весенние грибы, сморчки и строчки, традиционно не употреблялись в пищу в Ярославской губернии, поскольку эти грибы появились от сморчков и плевков «окаянного», который бежал от Грозы (ед. хр. 3, л. 4). Мораль легенды «Гроза и окаянный» разъясняет понятие страха Божия: «А бояться Грозы человеку не надо: кого Гроза убьет, того Бог грехами простит» (ед. хр. 3, л. 3). Страх перед чем-либо, кроме Бога, есть признак внутренней несвободы. Если от страха смерти христианину надлежит избавляться, то страх Божий, наоборот, надлежит приобретать и укреплять в себе.

В собрании Опочинина можно выделить группу легенд, в которых присутствуют образы животных. Здесь особенно четко прослеживается смешение библейских мотивов и отголосков мифов о почитаемых животных.

Мотив превращения человека в медведя находим в записанной Опочининым этиологической легенде «Откуда медведи пошли». Поймав «чудную рыбку», люди стали просить у нее «избы новые, и добра всякого - серебра, золота, одежи». Но им этого «показалось мало», тогда они «захотели царями быть и стали просить об этом рыбку». Человек, теряющий представление о данном ему при рождении положении и желающий большего, неминуемо будет наказан. Рыбка отвечает жадным людям: «Царство Богом дается. А за то, что вы этого захотели, быть вам медведями, а женам вашим - медведицами» (ед. хр. 5, 
л. 126-127). Данный сюжет присутствует в сказке Афанасьева «Жадная старуха», но отличается тем, что желания старухи там выполняет не чудесная рыбка, а дерево. О западноевропейском источнике этой сказки и литературной сказки А. С. Пушкина о рыбаке и рыбке писал М. К. Азадовский [Азадовский: 68].

Сходный сюжет есть в легенде, записанной Афанасьевым в Харьковской губернии. Злая жена и муж решили напугать свв. Апостолов Петра и Павла: надели на себя вывороченные шубы, притаились в укромном месте, а увидев подходящих к ним Апостолов, выскочили навстречу и заревели по-медвежьи. За это они были превращены в медведей [Афанасьев, 1914: 16]. Б. А. Успенский отмечает, что медведь в представлении русского народа относится к нечистой силе: считается, что он лешему родной брат [Успенский: 85].

В этиологических легендах животные нередко являются наряду с человеком не просто главными действующими лицами повествования, но и выступают в роли героев-антиподов: утратив чувство меры, потеряв смирение, разум, люди получают наказание, а беззащитные и терпеливые животные Божью милость. Это показано в одной из легенд из собрания А. Н. Афанасьева: за то, что бабы прокляли рожь, которую тяжело было жать, Господь хотел оставить их без хлеба; собаки попросили у Него хоть немного хлеба для себя и получили его в награду за скромность и терпение. Согласно легенде, с тех пор человек стал собирать только худые колосья - те, которые были предназначены для собак [Афанасьев, 1914: 14].

Сходный мотив наказания и вознаграждения присутствует и в легендах Опочинина «Собачья доля хлеба» (в двух версиях) и «Собачий хлеб» (ед. хр. 5, л. 135-141). Сюжет первой легенды состоит в том, что Господь, разгневавшись на людей, погубивших верблюда, хотел лишить их хлеба, но оставил немного зерен на самой верхушке колоса ради собаки, и «люди уже с тех пор живут собачьей долей хлеба» (ед. хр. 5, л. 140). Во второй легенде наказание людям следует за то, что одна баба обтерла блином обмаравшегося ребенка: «После этого на пять лет подряд был неурожай. Людям, не то что кормить собак, - самим-то есть было нечего. Вот и взвыли с голоду 
собаки, жаловались Богу. Услышал Господь собачью жалобу и стал посылать немного хлеба, - только на собак. - С той поры так и пошло: все родится мало хлеба, все в нем нехватка. И мы теперь едим "собачий хлеб”, потому что не на нас, грешных, а на одних собак посылает его Господь» (ед. хр. 5, л. 141). Во всех этих легендах наказание следует за небрежное отношение людей к дарам Бога, в частности - к такой ценности, как хлеб. Вместо благодарной молитвы человек посылает проклятья за обильный урожай: «Чтоб ты пропала, окаянная рожь», «Чтоб тебе ни всходу, ни умолоту!», «Чтоб тебя, проклятую, сдернуло снизу доверху!» [Афанасьев, 1914: 14]. За неблагодарность, лень, легкомыслие, гордость, гнев, небрежно сказанное слово ему посылается Божья кара.

Большая группа легенд из собрания Опочинина посвящена семейным отношениям. В них встречается один из основных мотивов народных легенд, отмеченный Веселовским, наказание за нарушение моральных норм, религиозных заповедей, общественного порядка. Часто в подобных легендах действуют герои-антиподы (сын-отец / мать, падчерица-родная дочь, две сестры или два брата), один из которых получает наказание, другой - вознаграждение. Примерами являются легенды «Про двух сестер», «Падчерица и родная дочка», «Бог даст - и в окошко подаст» (ед. хр. 5, л. 90-91, 109-114, 120-121). В последней легенде братья противопоставлены друг другу своей верой / неверием в Промысел Божий: они оба знают о зарытом кладе, но один брат торопит другого вырыть этот клад, чтобы другие их не опередили, а второй отказывается от своей доли, все время повторяя: «Бог даст - и в окошко подаст». Жаждущий наживы брат идет ночью в лес и в указанном месте находит телячью тушу вместо клада. Вернувшись в деревню, он в сердцах бросает ее в окно своему брату. При следующей встрече братьев выясняется, что в туше был зашит мешок с деньгами, которыми один брат поделился с другим. $\mathrm{B}$ «Сравнительном указателе...» этот сюжет можно соотнести с мотивом «предназначенного клада» (АТ 8342). [Сравнительный указатель сюжетов].

Так, в легенде «Нечестивый отец», записанной Опочининым, антиподами являются отец и сын: первый за отказ молиться 
был превращен в жеребца, сын же вымолил ему прощение у святого Николая. Узнал святителя герой легенды по его иконографии: «А сын глядит на него и признал его наконец: был старичок этот святой Николай Угодник, точь в точь, как видел он его в церкви на иконе». Отец получается прощение благодаря добродетелям его сына: «За твою сыновнюю любовь и набожность простит Господь твоего нечестивого отца» (ед. хр. 5, л. 89). Эта легенда близка по сюжету к легенде А. Н. Афанасьева «Грешная мать» (АТ 804), только в последней сын пытается вытащить мать из огненной реки, протягивая ей луковку. Афанасьевская легенда получила развитие в романе Ф. М. Достоевского «Братья Карамазовы», где ее рассказывает Алеше Грушенька. Легенда становится показателем того, что нарушенный порядок в душе Грушеньки восстанавливается, она возвращается к христианскому мировоззрению.

Легенды о святых и грешниках занимают в сказаниях, записанных Опочининым, самое значительное место. Это легенды о св. Николае, об Илье-пророке, св. Егории. О том, что Николай Чудотворец особенно любим народом, можно узнать в следующих легендах: «Про Николая Угодника и Илью-Пророка», «Как Никола Чудотворец и пророк Илья мужику пашню вспахали», «Св. Николай Чудотворец и поп» "Никола Угодник - помощник бедняка» (ед. хр. 5, л. 13-17, 18-19, 20-24, 26-27). Они повествуют о том, что св. Николай в народном сознании является заступником за крестьянина перед Ильей Пророком, пытается вразумить жадного попа и помогает бедному человеку выдать замуж дочерей, три раза одаривая его «грудой денег». Следует отметить, что легенда «Про Николая Угодника и Илью-Пророка» близка легенде из сборника Афанасьева «Илья и Никола», в которых объединяющим становится сюжет «мстительный святой» (АТ 846).

Также общим в легендах о грешниках является порицание пороков, которые проявляются при несоблюдении заповедей. Одна из них - почитание воскресного дня - распространяется на все сакральное время. Так, «беседы» (деревенские посиделки, в которых участвуют девушки и парни) не проводятся на святках, во время постов. Нарушение этого запрета приводит к тому, что беседа оказывается «запечатана» в избе 
на все время Рождественского поста, а раскрывается изба сама в Христову заутреню после удара колокола: «Видят: перед иконой свечка горит - все мертвые да страшные-престрашные» (ед. хр. 3, л. 80). Или девушки решили пошутить над братом умершей подруги, который в сороковины не ходит на беседы, и позвали его умершую сестру Олену. Придя, она «стала распутывать пряжу: вся синяя и страшная. А ее подруги после этого умерли» (ед. хр. 3 , л. 70).

Причиной наказания героев легенд также может стать такой грех, как винопитие. С изображением этого порока связан сквозной мотив легенд - мотив обмана или заблуждения: «нечистый всегда подстерегает пьяного и готов затащить его в болото или трущобу» [Афанасьев, 1914: 151]. В легенде, которую приводит Афанасьев, мужик, возвращаясь с пьяной пирушки, встречает незнакомца, который ведет его к себе и угощает чаркой. Мужик, взяв чарку, «перекрестился - глядь! стоит по горло в омуте, в руках кол держит, а товарища как не бывало!» [Афанасьев, 1914: 151]. В собрании Опочинина подобный мотив встречается в легенде «Товарищ», где дом, в который попадает солдат по приглашению встреченного им «товарища», оказывается западней: «куда не пойдет - все стены». Когда же солдат очнулся, оказался перед прорубью (ед. хр. 5, л. 75).

Мотив наваждения или заблуждения обнаруживается и в повестях Н. В. Гоголя «Вечера на хуторе близ Диканьки», в которых фантастическое, по замечанию Р. М. Хусаиновой, часто проявляется как неявное - через легенды, предания, а также с помощью мотивов сна («Майская ночь, или Утопленница»), слухов («Сорочинская ярмарка») [Хусаинова: 594]. Повесть «Заколдованное место» коррелирует с легендой «Товарищ»: оказавшись во власти страсти (к вину или к золоту), герой подвергается действию нечистой силы. Мотив наваждения или заблуждения объясняется духовной слепотой грешника - в этом писатель следует за народными легендами.

Сама выдумка хлебного вина, по народным преданиям, приписывается нечистым силам (АТ 817). Подтверждение этому находим у Афанасьева, который приводит рассказы татар Нижегородской губернии о том, что, приготовляя вино, черт подмешал туда сначала лисьей, потом волчьей, а потом 
и свиной крови: «От того если человек немного выпьет - голос бывает у него гладенький, слова масляные, так лисой на тебя и смотрит; а много выпьет - сделается у него свирепый волчий нрав; а еще больше выпьет - и как раз очутится в грязи, словно боров» [Афанасьев, 1914: 151]. Помимо этого Афанасьев подчеркивает, что в народных стихах и легендах винопитие осуждается, так как оно «потемняет человеку рассудок и вызывает его на всевозможные грехи и преступления» [Афанасьев, 1914: 149].

Осуждению в легендах из собрания Опочинина подвергается и сквернословие. Мысль об ответственности каждого за сказанное утверждается в легенде «Черное слово»: «Плохо бывает, когда, другой раз, не остережешься, выругаешься черным словом» (ед. хр. 5, л. 141), а также в легендах «Про двух проклятых девочек», «Проклятая дочка» (ед. хр. 5, л. 61-67). У Афанасьева есть похожие легенды с общим мотивом «проклятой дочери» (АТ 813А).

Среди часто встречающихся в религиозно-дидактических легендах мотивов можно выделить также и мотив обиды, затаенной злобы, которая приводит человека к преступлениям. В легенде «Удавленник» у Опочинина обида на отца приводит к самоубийству его сына Василия, который хотел убить отца за то, что тот его записал в рекруты, но, устыдившись своего злого умысла, в отчаянии повесился на рябине. Священник запретил матери поминать самоубийцу, но она завета не послушала, наварила кутью на Благовещенье, разбросала по дороге, чтобы птицы склевали ее и помянули сына. Однако птицы кутью не тронули (ед. хр. 5, л. 98-100). Таким образом, в мифологическом пространстве легенды и силы природы, и птицы, и святые угодники действуют в соответствии с неумолимой правдой воздаяния за грехи.

Отношение к самому страшному смертному греху - посягательству на свою жизнь - показано и в легенде «Как удавленник являлся своей матери»: здесь герой легенды утопил лодку хозяина и повесился, после смерти его душе нет покоя (ед. хр. 5, л. 107A-108). Душа героя отягощена еще и тем, что он уничтожил чужое имущество. 
Подобные мотивы получают отражение в сюжетной линии двух героев рассказа Л. Н. Толстого «Поликушка» (1862). Крепостной Поликей, потеряв доверенные ему барыней деньги, в отчаянии повесился - с этих пор душа его не знает покоя. После совершения Поликеем смертного греха от горя теряет рассудок его жена и гибнет новорожденный сын. Когда деньги находит богатый крестьянин Дутов, ему является призрак Поликея и заставляет выкупить из рекрутчины своего племянника Илью.

В основе легенды из собрания Опочинина «Грунины деньги» лежит мотив нарушения заповеди «не укради». Хотя отец Василий просто не успел вернуть долг из-за внезапной кончины, это становится бременем для его души: он является своей супруге во сне и просит вернуть деньги Груне. В конце легенды выводится мораль: «Чужая копейка - великое дело... И что касается души, то она камнем ее тянет, и пока ты ее не отдал кому надо, - кайся, не кайся, - не будет тебе покою и на том свете» (ед. хр. 5, л. 40-44). Чужое имущество здесь показано как ценность, потерю которой необходимо восполнить.

Уход из жизни праведников и грешников показывается в легендах по-разному. Так, в одной их них в сборнике Афанасьева - «Смерть праведнаго и грешнаго» - за душой первого приходят ангелы, которую кладут на золотую тарелку и с херувимской песней несут в рай, а грешного смерть убивает молотком в голову [Афанасьев, 1914: 137-138]. Афанасьев ссылается при этом на духовные стихи, перекликающиеся с легендами, про кончину двух Лазарей - бедного и богатого: душу бедного Лазаря бережно принимают на пелену и возносят на небо, душу богатого вынимают «скрозь ребра» и ввергают в «геенский огонь» [Афанасьев, 1914: 138]. В рукописях Опочинина также встречаются записи духовных стихов про двух братьев Лазарей, сюжет которых состоит из двух эпизодов: в первом - убогий брат приходит к богатому на пир под окно и просит подаяние, в чем богатый Лазарь ему отказывает: «Какой ты мне брат! / Сроду не бывал! Вон твоято братья - / Борзы кобели» (ед. хр. 5, л. 5). Второй эпизод посвящен молитве братьев о смерти и тому, что посылается им Господом: бедный просит тяжелую смерть за свои грехи - 
и получает «скору смерть», богатый просит легкой смерти, а получает страшную кончину. Душу праведного Лазаря ангелы положили «на тонку пелену» и понесли «ко самому Христу», а душу грешного Лазаря дьяволы вынимали «на острое копие» и «понесли его душеньку, / к самой сатане». Как не услышал мольбы бедного богатый Лазарь, так «не услышал Бог / молитву богатого» (ед. хр. 5, л. 5). Эти произведения объединяет сюжет «смерть праведника и грешника» (АТ 808).

Легенды из собрания Опочинина имеют ряд особенностей, обусловленных спецификой местности, где они были записаны. Это - Рыбинский уезд Ярославской губернии, жители которой неразрывно связаны с Волгой, бурлачеством, торговлей, путешествиями, отходничеством, охотой. В местных легендах обнаруживается так называемый «волжский текст».

Отдельные легенды, записанные Опочининым, посвящены водяному и русалке, живущей в Шексне (ед. хр. 5, л. 70-71, $72-74,128-130)$. В легенде «Водяной» знаком близости с нечистой силой становится движение наоборот («задом в воду зашел»). С реками связаны некоторые сны и видения героев. Так, в легенде «Вещий сон» герою снится, что на реку Черемуху «набежало народу видимо-невидимо». Оказалось, что народ действительно сбежался к реке после того, как герой утонул (ед. хр. 5, л. 92). В другой легенде три девушки отправились купаться, одна из них утонула, а другая, выбравшись на берег, рассказала, что ей привиделось, как священник в реке исповедал и причастил утонувшую, а ей отказал в причастии (ед. хр. 5, л. 39). Также в демонологических легендах Опочинина появляется «вольный», о котором собиратель легенд пишет: «Вольный - это создание народной фантазии, нечто вроде лесовика, лешего. Во всяком случае нечистая, не здешняя сила. 90-летний старик Василий Хамко, он же Чибес, утверждал, что “вольный” может появиться во всяком неблагословенном месте и в тех домах, где поминают нечистого. Он же водит людей, что без молитвы, не перекрестясь входят в лес (ед. хр. 3, л. 124).

В некоторых легендах из собрания Опочинина обнаруживается связь с европейскими сказаниями — «Как умершие мужья ходили к своим женам» и «Предсказательница, выходящая из 
реки Шексны» (ед. хр. 5, л. 45-46, 72-74). Сюжет первой легенды - посещение умершего мужа его живой женой — восходит к Старшей Эдде - к истории верной Сигрун и погибшего от рук ее родных Хельги: жена, не в силах забыть о своем умершем муже, мечтает о встрече с ним на брачном ложе (см. об этом: [Петрухин: 305-307]). О сходстве эпических жанров русского и европейского фольклора, о мотивах Старшей Эдды в литературе писали многие исследователи (см.: [Веселовский], [Топорова], [Сафрон], [Довгая], [Осьмухина], [Смирнова, Маслова, Мощанская], [Казаков], [Булавкин]), но мотив связи земного мира и загробного не исследован, хотя его можно обнаружить в балладе Г. Бюргера «Ленора» (1773), стихотворении Э. По «Линор» (1843), новелле В. Ирвинга «Жених-призрак» (1819). В народных легендах порицается то, что женщина не может примириться с утратой мужа, а также отсутствие у нее веры в Воскресение. Необходимость примирения со смертью близкого человека и вера в бессмертие его души восходит к Новому Завету, к словам Апостола Павла: «Как в Адаме все умирают, так во Христе все оживут» (1 Кор. 15:22). В русской литературе этот сюжет был обработан В. А. Жуковским в балладе «Людмила» (1808).

Вторая легенда также восходит к одному из эпизодов Старшей Эдды о древе Иггдрасиль с источником судьбы при корнях [Буслаев: 332]. В легенде «Предсказательница, выходящая из реки Шексны» создается образ мудрой девы, которая помогает людям - предрекает будущие потери. Во многих славянских сказках появляется «вещая дева при истоке реки» [Буслаев: 332]. По мнению Ф. И. Буслаева, в подобных легендах и сказаниях происходит «олицетворение стихийных божеств» и «духов предков» [Буслаев: 320]. Сюжет этого древнего сказания лег в основу повести немецкого романтика Ф. де ла Мотт Фуке «Ундина» (1801) и был поэтически обработан В. А. Жуковским в поэме 1836 г. с одноименным названием. Кроме того, образ девы-русалки получил отражение в стихотворении Г. Гейне «Лорелей» (1824), в драме Г. Гауптмана «Потонувший колокол» (1896). Так, А. П. Склизкова считает мифологический план драмы Гауптмана свидетельством ее принадлежности неоромантическому направлению, русалка Раутенделейн 
в этом произведении, по мнению исследователя, воплощает трансцендентные силы, она освобождает героя от смерти [Склизкова: 113, 117].

Основным отличием легенды, записанной Опочининым, от литературных произведений, где на первый план выходит история любви русалки и земного человека, является то, что в ней русалка - предсказательница гибели людей и судов, появляющаяся на самом опасном участке реки Шексны: «На расстоянии версты от села Вольского Погоста, в Рыбинском уезде, река Шексна делает крутой поворот и образует т. н. Черный мыс, чаще называемый в народе - "Кривая" - крутой берег мыса, в который ударяет сильное течение реки, с каждым годом отмывается и глубина здесь весьма значительна» (ед. хр. 5, л. 72). Также в легенде упоминается о реальном событии - гибели в 1894 г. парохода «Успех». Белые одежды русалки вызывают ассоциацию с традиционным цветом погребального савана: «Издавна же существует поверье, что каждому несчастью в “Кривом” предшествует появление из воды девицы в белой одежде, с неприкрытыми, распущенными волосами» и голосом, похожим на стон гагар (ед. хр. 5, л. 72). Сделав предсказание, шекснинская русалка бросается с крутого берега, уреза, в воду. Старый рыбак рассказывает о том, что у него после встречи со зловещей предсказательницей пропала «сила в руках», он грести не мог. В поединке с нечистой силой ему помогает крестное знамение.

Таким образом, легенды, собранные Е. Н. Опочининым в Рыбинском уезде Ярославской губернии, имеют сходство с легендами из сборника А. Н. Афанасьева и других собраний фольклора. Общими являются сюжеты «срок жизни людей и животных» (АТ 828), «предназначенный клад» (АТ 8342), «мстительный святой» (АТ 846), «проклятая дочь» (АТ 813А), «смерть праведника и грешника» (АТ 808). Данные сюжеты связаны с аксиологическими мотивами (простейшими ценностными ориентирами, закрепленными в образцах поведения). Сюжеты «предназначенный клад» и «смерть праведника и грешника» объединены мотивом восстановления нарушенного порядка, первый сюжет связан с мотивом веры в Промысел Божий, а сюжет «мстительный святой» предполагает 
заступничество святого, сюжет же «проклятая дочь» побуждает к чувству ответственности за сказанное слово.

Свойством типологической повторяемости отличаются мотивы заступничества святых угодников и добродетельных детей за грешников, что раскрывает веру в возможность их нравственного возрождения. В то же время, наказание за пьянство, сквернословие, маловерие, посягательство на чужое имущество, за непочитание сакрального времени - это варианты восстановления нарушенного порядка в мире. Утрата смирения, чувства меры, небрежение дарами Бога - это варианты мотива нарушения божественного порядка, за которым следует мотив наказания, который реализуется в таких вариантах, как превращение человека в зверя, голод, смерть.

Инвариантами для мировой литературы становятся мотивы неверия в Воскресение, наказания за нарушение иерархии в земном мире и связи вещей девы-русалки с загробным миром. В сюжетах произведений русской литературы развиваются такие фольклорные мотивы, как мотив наваждения или духовной слепоты из-за страстей, овладевающих человеком, мотив наказания за обиду на родных. Отличаются легенды из собрания Опочинина не только «волжским текстом», но и мотивом страха Божия, который заставляет человека перейти от мифологического циклического времени к христианской линейной концепции времени. Все аксиологические мотивы можно дифференцировать на мотивы нарушения божественного порядка и его восстановления. В общих мотивах русского фольклора и литературы выступают такие нравственные ценности, как молитва, почитание святых и их образов, соблюдение иерархии в семье и в обществе, труд, честность, трезвенность, милосердие и взаимопомощь, ответственность за слова и дела, вера в Промысел Божий. Эти духовно-нравственные доминанты определяют картину мира русского человека.

\section{Примечание}

1 Сборник народных легенд, работа над которым велась с 1909 по 1916 г., так и не был опубликован. Записи легенд сохранились лишь в рукописях в фондах Российского государственного архива литературы и искусства (РГАЛИ. Ф. 361. Оп. 1. Ед. хр. 3-5). Далее ссылки на этот источник приводятся в тексте статьи с указанием единицы хранения и листов в круглых скобках. 


\section{Список литературы}

1. Азадовский М. К. Литература и фольклор: Очерки и этюды. - Л.: Худож. лит., 1938. - 297 с.

2. Азбелев С. Н. Проблемы международной систематизации преданий и легенд // Русский фольклор: Специфика фольклорных жанров. - М.; Л.: Наука, 1966. - Т. 10. - С. 176-195.

3. Афанасьев А. Н. Народные русские сказки: в 8 вып. - М.: Изд. К. Солдатенков и Н. Щепкин, 1855-1863. - Вып. 1-8.

4. Афанасьев А. Н. Народные русские легенды / ред. и предисл. С. К. Шамбинаго. - М.: Книгоизд-во «Современные проблемы», 1914. - 316 с.

5. Булавкин К. В. Древнерусский стих о Голубиной книге в контексте евразийской мифологической традиции // Вестник Московского государственного областного гуманитарного института. Серия: История, философия, политология, право. - 2012. - № 2. - С. 21-27.

6. Буслаев Ф. И. Славянские сказки // Исторические очерки русской народной словесности и искусства: в 2 т. - СПб.: Типография товарищества «Общественная польза», 1861. - Т. 1. - С. 308-354.

7. Веселовский А. Н. Опыты по истории развития христианской легенды // Журнал министерства народного просвещения. - 1875. - Ч. 178 (№4. Апрель). - С. 283-331. - Ч. 179 (№ 5. Май). - С. 48-130; 1876. - Ч. 183 (№ 2. Февраль). - С. 241-288. - Ч. 184 (№ 3. Март). - С. 50-116; 1877. Ч. 189 (№ 2. Февраль). - С. 186-252. — Ч. 191 (№ 5. Май). - С. 76-125.

8. Веселовский А. Н. Историческая поэтика / ред., вступ. ст. и примеч. В. М. Жирмунского. - М.: Изд-во ЛКИ, 2017. - 648 с.

9. Довгая Ю. В. Архетипические сюжеты в европейской литературе // Культурология. - 2001. — № 2 (18). - С. 69-77.

10. Зуева Т. В. Легенда // Литературная энциклопедия терминов и понятий / гл. ред. А. Н. Николюкин. - М.: НПК «Интелвак», 2001. - С. 432-434.

11. Казаков Г. М., Петров Н. В. Сюжетные функции перебранок в эпической поэзии (саги и былины) // Вестник РГГУ. Серия: История, филология, культурология, востоковедение. — 2011. — № 9 (71). - С. 84-107.

12. Левинтон Г. А. Легенды и мифы // Мифы народов мира. Энциклопедия: в 2 т. / гл. ред. С. А. Токарев. - М.: Сов. энциклопедия, 1992. - Т. 2. C. $45-47$.

13. Назиров Р. Г. Запрет оглядываться (к происхождению фольклорного мотива) // Фольклор народов РСФСР. Межэтнические фольклорные связи. Межвузовский научный сборник. - Уфа: Изд-во Башкирского ун-та, 1987. - С. 31-38.

14. Осьмухина О. Ю. «Священная книга оборотня» В. Пелевина: мифопоэтический аспект // Литературоведение на современном этапе: теория, история литературы, творческие индивидуальности. К 130-летию со дня рождения Е. И. Замятина. По материалам международного конгресса литературоведов. - 2014. - С. 399-404.

15. Петрухин В. Я. Мифы древней Скандинавии. - М.: Астрель; АСТ, 2010. $-464 \mathrm{c}$. 
16. Проблемы современного сравнительного литературоведения / под ред. Н. А. Вишневской и А. Д. Михайлова. - М.: ИМЛИ РАН, 2004. - 96 с.

17. Пропп В. Я. Легенда // Пропп В. Я. Поэтика фольклора. - М.: Лабиринт, 1998. - С. 125.

18. Пыпин А. Н. Русские народные легенды. (По поводу издания г-на Афанасьева в Москве 1860 г.) // Народные русские легенды А. Н. Афанасьева / предисл., сост. и коммент. В. С. Кузнецовой. - Новосибирск: Наука, Сиб. отд-ние, 1990. - С. 180-202.

19. Сафрон Е. А. Традиции «Старшей Эдды» в скандинавской фэнтези (на материале романов Е. А. Дворецкой) // Текст, контекст, интертекст. Сб. науч. ст. по материалам Международ. науч. конф. «XIII Виноградовские чтения» (г. Москва, 15-17 октября 2013). - М.: МГПУ, 2014. - T. III. - C. 45-52.

20. Силантьев И. В. Поэтика мотива / отв. ред. Е. К. Ромодановская. - М.: Языки славянской культуры, 2004. - 296 с.

21. Скафтымов А. П. Нравственные искания русских писателей: статьи и исследования о русских классиках / сост. Е. И. Покусаева; вступ. ст. Е. И. Покусаева и А. А. Жук. - М.: Худож. лит., 1972. - 544 с.

22. Склизкова А. П. Драма-сказка Г. Гауптмана «Потонувший колокол» как неоромантическое произведение // Вестник Пермского университета. - 2016. - Вып. 2 (34). - С. 113-119.

23. Смирнова Н. А., Маслова М. А., Мощанская О. Л. Художественная рецепция «Прорицания Вельвы» в творчестве Дж. Р. Р. Толкина и В. Я. Брюсова // Русско-зарубежные литературные связи. Межвуз. сб. науч. тр. - Н. Новгород: НГПУ, 2014. - Вып. VI. - С. 221-228.

24. Сравнительный указатель сюжетов. Восточнославянская сказка / сост. Л. Г. Бараг, И. П. Березовский, К. П. Кабашников, Н. В. Новиков. - Л.: Наука, 1979. - 442 с.

25. Топорова Т. В. О мифологизме Н. В. Гоголя: «Страшная месть» vs «Старшая Эдда» // Вопросы филологии. - 2009. - № 2. - С. 59-67.

26. Успенский Б. А. Филологические разыскания в области славянских древностей. Реликты язычества в восточно-славянском культе Николая Мирликийского. - М.: Изд-во МГУ, 1982. — 248 с.

27. Ухтомский А. А. Значение легендарной поэзии в древнерусской литературе и жизни // Доминанта души. - Рыбинск: Рыбинское подворье, 2000. - С. $15-36$.

28. Хоружий С. С. Вещь в работе $<$ Критические очерки европейской антропологии>. 2006 [Электронный ресурс] // Портал «Институт синергийной антропологии». — URL: http://synergia-isa.ru/?page_id=4301 (05.05.2018).

29. Хусаинова Р. М. Типы фантастического в повестях сборника «Вечера на хуторе близ Диканьки» Гоголя // Вестник Башкирского университета. Филология и искусствоведение. - 2014. - Т. 19. - № 2. - С. 592 -595.

30. Чистов К. В. Русская народная утопия (генезис и функции социальноутопических легенд). - СПб.: Дмитрий Буланин, 2003. - 540 с. 
Информация об авторах: Федорова Елена Алексеевна- доктор филологических наук, доцент кафедры теории и практики коммуникации Ярославского государственного университета им. П. Г. Демидова, научный сотрудник Рыбинского государственного историко-архитектурного и художественного музея; Ковалева Ирина Федоровна- аспирант Ярославского государственного педагогического университета им. К. Д. Ушинского, руководитель проектов ООО «АРТ-ХОЛДИНГ “МЕДИАРОСТ”».

Дата поступления в редакцию: 22.05.2018

Дата публикации: 01.10.2018

Elena A. Fedorova

(Yaroslavl, Rybinsk, Russian Federation)

sole11@yandex.ru

Irina F. Kovaleva

(Rybinsk, Russian Federation)

kirinaf@yandex.ru

\title{
The Genre Content of Folk Legends in Literary Interpretation by E. N. Opochinin
}

\begin{abstract}
The article offers the analysis of genre and subject features of literary interpretations of the folk legends put together by E. N. Opochinin in Rybinsk County of Yaroslavl province (1909-1916). These legends have not yet been introduced for scientific use that makes the research challenging. The comparison of the legends with the those written down by A. N. Afanasyev allows expanding the idea about spiritual and moral values of Russian people. The legend as a genre is a tool of maintenance of subject elements of mythology. The axiological functions of its motives appear in the plot. Legends can be divided into those which refer to the violation of a divine order, and those which touch upon its restoration. Legends reveal the particularities of Christian outlook: via a prayer, veneration of Saints and their images, respecting for the family and social hierarchy, work, honesty, sobriety, mercy and mutual aid, responsibility for words and deeds, belief in Divine Providence. The "Memory of a genre" of a legend can be traced in literary works. The Violation of the Divine Order in legend and literary works results in the loss of humility and a sense of proportion, the lack of faith, offense against one's property. The broken order is restored thanks to the protection of Saints and virtuous children for sinners.
\end{abstract}

Keywords: E. N. Opochinin, national legend, plot, motif, genre, axiology, spiritual and moral values, "memory of a genre" in literature 


\section{References}

1. Azadovskiy M. K. Literatura i fol'klor: Ocherki $i$ etyudy [Literature and Folklore: Essays and Sketches]. Leningrad, Khudozhestvennaya literatura Publ., 1938. 297 p. (In Russ.)

2. Azbelev S. N. Problems of the International Arrangment of Traditions and Legends. In: Russkiy fol'klor: Spetsifika fol'klornykh zhanrov [Russian Folklore: The Particularity of Folklore Genres]. Moscow, Leningrad, Nauka Publ., 1966, vol. 10, pp. 176-195. (In Russ.)

3. Afanas'ev A. N. Narodnye russkie skazki: v 8 vypuskakh [Russian Folk Tales: in 8 Issues]. Moscow, Izdatel'stvo K. Soldatenkova i N. Shchepkina Publ., 1855-1863, issue 1-8. (In Russ.)

4. Afanas'ev A. N. Narodnye russkie legendy [Russian Folk Legends]. Moscow, Sovremennye problemy Publ., 1914. 316 p. (In Russ.)

5. Bulavkin K. V. The Old Russian Line About Golubinaya Book in the Context of Eurasian Mythological Tradition. In: Vestnik Moskovskogo gosudarstvennogo oblastnogo gumanitarnogo instituta. Seriya: Istoriya, filosofiya, politologiya, pravo [Moscow State Regional Institute of Humanities. Series: History, Philosophy, Political Science, Law], 2012, no. 2, pp. 21-27. (In Russ.)

6. Buslaev F. I. Slavic Tales. In: Istoricheskie ocherki russkoy narodnoy slovesnosti i iskusstva: $v 2$ tomakh [Historical Essays of Russian Folk Literature and Art: in 2 Vols]. St. Petersburg, Tipografiya tovarishchestva Obshchestvennaya pol'za Publ., 1861, vol. 1, pp. 308-354. (In Russ.)

7. Veselovskiy A. N. Experiments on the History of the Development of the Christian Legend. In: Zhurnal ministerstva narodnogo prosveshcheniya [The Journal of the Ministry of National Education], 1875, part 178 (no. 4. April), pp. 283-331; 1875, part 179 (no. 5. May), pp. 48-130; 1876, part 183 (no. 2. February), pp. 241-288; part 184 (no. 3. March), pp. 50-116; 1877, part 189 (no. 2. February), pp. 186-252; part 191 (no. 5. May), pp. 76-125. (In Russ.)

8. Veselovskiy A. N. Istoricheskaya poetika [Historical Poetics]. Moscow, LKI Publ., 2017. 648 p. (In Russ.)

9. Dovgaya Yu. V. Archetypal Plots in European Literature. In: Kul'turologiya, 2001, no. 2 (18), pp. 69-77. (In Russ.)

10. Zueva T. V. The Legend. In: Literaturnaya entsiklopediya terminov i ponyatiy [Literary Encyclopedia of Terms and Concepts]. Moscow, Intelvak Publ., 2001, pp. 432-434. (In Russ.)

11. Kazakov G. M., Petrov N. V. Squabbles as a Plot Devices in the Epic Poetry (Sagas and Bylinas). In: Vestnik Rossiyskogo gosudarstvennogo gumanitarnogo universiteta. Seriya: Istoriya, filologiya, kul'turologiya, vostokovedenie [RGGU Bulletin. Series: History. Philology. Cultural Studies. Oriental Studies], 2011, no. 9 (71), pp. 84-107. (In Russ.)

12. Levinton G. A. Legends and Myths. In: Mify narodov mira. Entsiklopediya: $v 2$ tomakh [Myths of the Peoples of the World. Encyclopedia: in 2 Vols]. Moscow, Sovetskaya entsiklopediya Publ., 1992, vol. 2, pp. 45-47. (In Russ.) 
13. Nazirov R. G. The Prohibition to Look Back (On the Origins of the Folklore Motif). In: Fol'klor narodov RSFSR. Mezhetnicheskie fol'klornye svyazi [Folklore of the Peoples of the RSFSR. Interethnic Folklore Relations]. Ufa, Bashkir State University Publ., 1987, pp. 31-38. (In Russ.)

14. Os'mukhina O. Yu. "The Sacred Book of the Werewolf” by V. Pelevin: Mythopoetic Aspect. In: Literaturovedenie na sovremennom etape: teoriya, istoriya literatury, tvorcheskie individual'nosti. K 130-letiyu so dnya rozhdeniya E. I. Zamyatina [Literary Studies at Present: Theory, History of Literature, Artistic Individualities. On the Occasion of the 130th Anniversary of the Birth of E. I. Zamyatin], 2014, pp. 399-404. (In Russ.)

15. Petrukhin V. Ya. Mify drevney Skandinavii [Myths of Ancient Scandinavia]. Moscow, Astrel' Publ., AST Publ., 2010. 464 p. (In Russ.)

16. Problemy sovremennogo sravnitel'nogo literaturovedeniya [Problems of Contemporary Comparative Literary Studies]. Moscow, Institute of World Literature, Russian Academy of Sciences Publ., 2004. 96 p. (In Russ.)

17. Propp V. Ya. Legend. In: Propp V. Ya. Poetika fol'klora [Propp V. Ya. The Poetics of Folklore]. Moscow, Labirint Publ., 1998, p. 125. (In Russ.)

18. Pypin A. N. Russian Folk Legends (Concerning the Edition of Mr. Afanasyev's Work in Moscow, 1860). In: Narodnye russkie legendy A. N. Afanas'eva [Russian Folk Legends by A. N. Afanasyev]. Novosibirsk, Nauka Publ., 1990, pp. 180-202. (In Russ.)

19. Safron E. A. Traditions of "The Elder Edda" in Scandinavian Fantasy (Based on the Novels of E. A. Dvoretskaya). In: Tekst, kontekst, intertekst [Text, Context, Intertext]. Moscow, Moscow City Pedagogical University Publ., 2014, vol. 3, pp. 45-52. (In Russ.)

20. Silant'ev I. V. Poetika motiva [The Poetics of Motif]. Moscow, Yazyki slavyanskoy kul'tury Publ., 2004. 296 p. (In Russ.)

21. Skaftymov A. P. Nravstvennye iskaniya russkikh pisateley: stat'i i issledovaniya o russkikh klassikakh [Moral Aspirations of Russian Writers: Articles and Researches on Russian Classics]. Moscow, Khudozhestvennaya literatura Publ., 1972. 544 p. (In Russ.)

22. Sklizkova A. P. G. Hauptmann's Fairy Drama “The Sunken Bell" as a Neoromantic Work. In: Vestnik Permskogo universiteta [Perm University Herald], 2016, issue 2 (34), pp. 113-119. (In Russ.)

23. Smirnova N. A., Maslova M. A., Moshchanskaya O. L. Artistic Reception of "Prophecy of the Volva (Seeress)" in the Works of J. R. R. Tolkien and V. Ya. Bryusov. In: Russko-zarubezhnye literaturnye svyazi [Russian-Foreign Literary Relations]. Nizhny Novgorod, Kozma Minin Nizhny Novgorod State Pedagogical University Publ., 2014, issue 6, pp. 221-228. (In Russ.)

24. Sravnitel'nyy ukazatel' syuzhetov. Vostochnoslavyanskaya skazka [Comparative Index of Plots. Eastern-Slavic Fairy Tale]. Leningrad, Nauka Publ., 1979. 442 p. (In Russ.)

25. Toporova T. V. On Gogol's Mythologism: a Comparison of "A Terrible Vengeance" with "The Elder Edda". In: Voprosy filologii [Journal of Philology], 2009, no. 2, pp. 59-67. (In Russ.) 
26. Uspenskiy B. A. Filologicheskie razyskaniya v oblasti slavyanskikh drevnostey. Relikty yazychestva $v$ vostochno-slavyanskom kul'te Nikolaya Mirlikiyskogo [Philological Researches in the Slavic Antiquities: The Relics of Paganism in the East Slavic Cult of Nicholas of Myra]. Moscow, Lomonosov Moscow State University Publ., 1982. 248 p. (In Russ.)

27. Ukhtomskiy A. A. The Value of the Legendary Poetry in Old Russian Literature and Life. In: Dominanta dushi [The Dominant of the Soul]. Rybinsk, Rybinskoe podvor'e Publ., 2000, pp. 15-36. (In Russ.)

28. Khoruzhiy S. S. Veshch'v rabote $<$ Kriticheskie ocherki evropeyskoy antropologii $>$ [The Thing in Use <Critical Sketches of the European Anthropology $>$ ]. Available at: http://synergia-isa.ru/?page_id=4301 (accessed on May 5, 2018).

29. Khusainova R. M. Fantasy in the Collection of Stories "Evenings on a Farm Near Dikanka” by N. V. Gogol. In: Vestnik Bashkirskogo universiteta: Filologiya $i$ iskusstvovedenie [Bulletin of Bashkir University: Philology and Art Studies], 2014, vol. 19, no. 2, pp. 592-595. (In Russ.)

30. Chistov K. V. Russkaya narodnaya utopiya (genezis i funktsii socialno-utopicheskikh legend) [Russian Folk Utopia (Genesis and Functions of Social-Utopian Legends)]. St. Petersburg, Dmitriy Bulanin Publ., 2003. 540 p. (In Russ.)

Information about the authors: Fedorova Elena A.- Doctor of Philology, Associate Professor of the Department of Theory and Practice of Communication of P. G. Demidov Yaroslavl State University, Researcher at the Rybinsk State History, Architecture and Art Museum-Preserve; Kovaleva Irina F. - Post Graduate Student of Yaroslavl State Pedagogical University named after K. D. Ushinsky, Project Manager of Art Holding "Mediarost" LLC.

Received: May 22, 2018 Date of publication: October 1, 2018 